\title{
Tradition and Modernism: Sustainable Rice Culture
}

\author{
Dave Flynn ${ }^{1}$ \\ ${ }^{1}$ Hofstra University, Hempstead \\ Correspondence: Dave Flynn, Department of Management, Frank G. Zarb School of Business, Hofstra University, \\ Hempstead, NY 11549. E-mail: Dave.Flynn@Hofstra.edu
}

Received: March 3, 2014 Accepted: March 20, 2014 Online Published: April 14, 2014

doi:10.5430/sass.v1n2p1 URL: http://dx.doi.org/10.5430/sass.v1n2p1

\begin{abstract}
Japan has defended its 778 percent tariffs on rice as the sacred crop grown by farmers who defend a proud agrarian heritage that forms the nation's spiritual center (Tabuchi, 2014: B1). However, the rice industry may not be sustainable as it is presently structured in an increasingly freer trade world. Arguably, the average size of rice farms in Japan of approximately 1 hectare of land (2.5 acres, approximately) is not sustainable. In 2009, according to government statistics, the average size of a farm in Japan was just 1.9 hectares, or 4.7 acres, in 2009, compared with 198 hectares in the United States (Tabuchi, 2010). Herein, we will explore the historical and cultural context of rice farming and ultimately, make recommendations for how to make rice farming more sustainable.
\end{abstract}

Keywords: sustainable development, duality of culture, rice farm size, hybrid farming techniques

\section{Rice and Culture in Japan}

As suggested by Wojtan (1993), many believe that the following aspects of Japanese social behavior originate from wet rice cultivation: the notion of wa (harmony), consensus-seeking, and the assessment of the context of actions. Some even include the concept of amae (feelings of dependency). Historically, wet rice cultivation was a labor-intensive task that could not be accomplished easily. As a result, families pooled their labor. More importantly, they also shared their water resources and irrigation facilities. Typically, irrigation arrangements called for water to run downhill, linking all the surrounding families in their shared destiny of communal resource usage. Further, people lived in houses clustered together and depended heavily upon each other since the rice was usually planted on the same day after several days of watering. This necessitated an emphasis on group interests, the enhancement of skills in group decision-making and the avoidance of friction between families who would be neighbors and workmates for generations. This historic commitment to group harmony, a hallmark of the original culture of rice, echoes today and continues to shape group consciousness. Despite the fact that a small number of people actually grow rice, 126.66 million people still try to sustain group harmony, as they seek daily accommodation in a relatively confined space. As an aside, the population of Japan decreased by a record 244,000 people in 2013 according to the Japan Times.

As Egenter (1996) states "anyone who takes these peasant customs as a serious source of information and tries to understand them in their existential aspects and in their intensive use of signs will soon begin to see the seemingly unreasoned procedures as traditional remnants of a prehistoric field organization. The rice farmers who came to the islands in the Yayoi era did not live in a vacuum. The early history of Japan and the establishment of the Yamato state clearly reveal the clashes that took place with other ethnic groups. The Japanese islands at that time comprised many countries and many peoples, as is still the case with parts of the Indonesian archipelago. The various settlers defined their boundaries and accepted certain ordering principles so as to be able to live side by side. The rice rituals have retained some vestiges of these orders."

"We are justified to talking of a rice culture by the philosophical basis of this environmental structure. Its landmarks are concrete: path and place, gateway and house, field and woods, water and soil, mountain and river. It does not plunder nature, but makes only temporary use of parts of it. Man is a guest who receives gifts from nature, and gives some of his own possessions reverently in return. That is no doubt the deeper meaning of the numerous rites and sacrifices of rice and rice wine. They are the modest expression of a local attitude to life which seeks, by harmonizing the opposites of nature and culture, to create the prerequisites of human and humane existence." 


\section{Tradition versus Modernism}

In $300 \mathrm{BCE}$, (approximately), the Jamon culture was displaced by the Yayoi culture that brought irrigated rice cultivation from Korea. Recently, eleven grains of brown rice believed to date back to the early Yayoi period, around 2,600 to 2,400 years ago, were found at the location of a former paddy in the Akitsu archaeological site in Goze, Nara Prefecture. Kyoto University Prof. Tatsuya Inamura, an expert on plant production systems, revealed the discovery at a research meeting of Nara Prefecture's Archaeological Institute of Kashihara on Jan. 12. The rice grains, which were first excavated in November, were brown and about four millimeters in length. The rice did not have husks. The grains are believed to have been so well preserved because they were sealed in mud with high water content and were not exposed to air. It is rare to discover rice from the Yayoi period that has not undergone carbonization (Yomiuri Shinbum, 2014).

Japan has borrowed cultural artifacts from other cultures and woven them in their own fabric sometimes referred to as cultural transposition by Hofstede (1980). It is well noted that the Meiji Restoration of 1868 established a policy of openness to the outside world that sent emissaries beyond Japanese shores to identify new methods and ideas to be incorporated into a modernizing Japan.

The concept of there being a duality of modern and traditional values in Japan has been observed over many centuries (see e.g. Flynn, 1982; Murayama, 1971). As stated by Murayama (1971:15) "racial distribution in Japan is homogenous, [however] Japanese culture is heterogeneously mixed so as to result in the improvement of the Japanese core character." Furthermore, there is empirical evidence that reveals Japanese managers embracing western values as they remain in the United States for longer periods of time (Reichel \& Flynn, 1983). However, there also are distinct Japanese values when compared to Koreans and Chinese (Flynn et al., 2006).

\section{Sustainable Farm Techniques}

As discussed earlier (Flynn, 2012), a sustainable economy must limit withdrawals from, and produce investments in all forms of capital (human, social, and natural) to ensure that no form of capital is diminished in order to increase short-term output of marketable goods and service (Lant, 2004:22). "Sustainability of human activities (predominantly production and consumption) is a growing concern among businesses, customers, governments, international bodies and non-governmental organizations. These concerns are often linked to energy efficiency, reduction of environmentally harmful emissions, ecosystem preservation and other conservation efforts. They are becoming a part of a "triple bottom line" for business accounting: financial, social and environmental" (Hermanowicz, 2005).

As noted by Nguu Van Nguyen, Secretary, International Rice Commission, rice is the staple food of more than 3,000 million people. Global rice production, however, has become unstable after 1999. The surge in rice prices since 2007 has affected food security in several developing countries where rice is the staple food crop. The rate of growth of rice yield increases is declining, while water and land resources for rice production - especially in Asia - are becoming scarce. The food security of rice consumers depends, therefore, on greater national, regional and international efforts and investments toward achieving sustainable production increases. Policy makers need information on the situation of rice production and on improved technologies that are available for sustainable intensification of rice production in order to formulate appropriate policies for supporting rice production.

Global rice production was only 215 million tons in 1961, after thousands of years from the time when rice cultivation first took place. Within the span of 45 years the global rice production rose to 644 million tons in 2006 or an increase of 429 million tons. During the first 15 years, 1961 to 1975, global rice production increased by 141 million tons or 9.4 million tons per year. Increases in both harvested area and yield were responsible for the increase of global rice production from 1961 to 1975 . Global rice harvested area increased by 26 million hectares or 1.73 million hectares/year, while world rice yield increased by 0.65 tons/hector or only 43 kilograms/year. In the next 15 years, 1976 to 1990 , the global rice production increased rapidly by 171 million tons or 11.4 million tons per year. During this period, the global rice harvested area, however, increased only 5 million hectares or 0.33 million hectares/year, while the world rice yield increased 1.07 tons/hector or 0.071 tons/year. Productivity increase, therefore, was the main factor behind the increase of global rice production during this period. Furthermore, as suggested above rice production has decreased from 2000 to 2013 (please see Table 1 and 2). 
Table 1. Milled Rice Production by Country in 1000 MT (2013 estimate)

Rank Country
$1 \underline{\text { China }}$
$2 \underline{\text { India }}$
$3 \underline{\text { Indonesia }}$
$4 \underline{\text { Bangladesh }}$
$5 \underline{\text { Viet Nam }}$
$6 \underline{\text { Thailand }}$
$7 \underline{\text { Philippines }}$
$8 \underline{\text { Myanmar }}$
$9 \underline{\text { Brazil }}$
$10 \underline{\text { Japan }}$
$11 \underline{\text { United States }}$
$12 \underline{\text { Pakistan }}$

Production (1000 MT)

$$
\begin{array}{r|}
141,500.00 \\
103,000.00 \\
37,700.00 \\
34,400.00 \\
27,700.00 \\
20,500.00 \\
11,640.00 \\
11,000.00 \\
8,200.00 \\
7,720.00 \\
6,014.00 \\
6,000.00
\end{array}
$$

Source: http://www.indexmundi.com/agriculture/?commodity=milled-rice\&

Table 2. Rice Production (1000 tons) and Harvested Area (1000 hectares) and Arable Land (1000 hectares in some selected countries in 2000)

$\begin{array}{lccl}\begin{array}{l}\text { Rice Production } \\ \text { (1000 tons })\end{array} & \begin{array}{c}\text { Rice harvested area } \\ (1000 \text { hectares })\end{array} & \begin{array}{c}\text { Arable land } \\ (1000 \text { hectares })\end{array} & \text { Rice harvested area/Arable land } \\ \text { China 190,668 } & 30,503 & 124,144 & 0.245 \\ \text { India 134,150 } & 44,600 & 161,500 & 0.276 \\ \text { Indonesia 51,000 } & 11,523 & 17,941 & 0.642 \\ \text { Bangladesh 25,521 } & 10,700 & 7,992 & 1.338 \\ \text { Viet Nam 32,554 } & 7,655 & 5,700 & 1.342 \\ \text { Thailand 23,403 } & 10,048 & 16,800 & 0.598 \\ \text { Myanmar 20,125 } & 6,211 & 9,548 & 0.650 \\ \text { Philippines 12,415 } & 4,037 & 5,500 & 0.734 \\ \text { Japan 11,863 } & 1,770 & 4,535 & 0.390 \\ \text { Brazil 11,168 } & 3,672 & 53,200 & 0.006 \\ \text { USA 8,669 } & 1,232 & 176,950 & 0.069\end{array}$

Source: www.fao.org/fileadmin/templates/agphome/documents/Rice/sustintriceprod.pdf

The United States Department of Agriculture estimates the 2012/13 rice area at 1.55 million hectares, down 26,000 hectares from last year and down about 120,000 hectares from 5 years ago (2007/08). The current rice crop was transplanted in early May (about 1 month before the time of the trip) and was in the early vegetative/tillering stage. The weather at planting was generally favorable and Japanese officials said the crop was growing normally (please see Figure 1 \& Figure 2). 


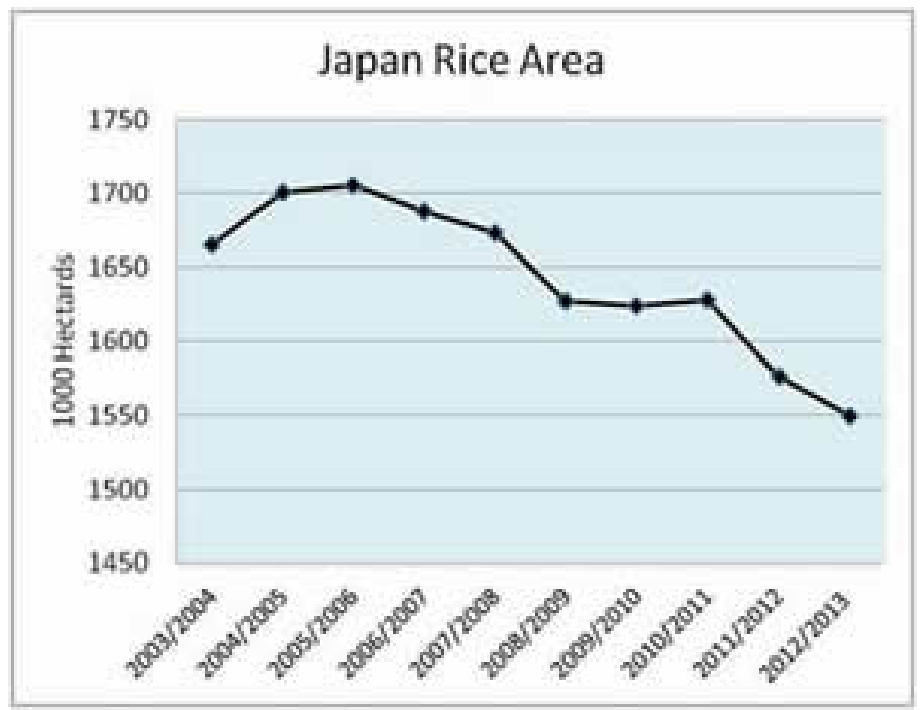

Figure 1.

Source: http://www.pecad.fas.usda.gov/highlights/2012/08/Japantrip/

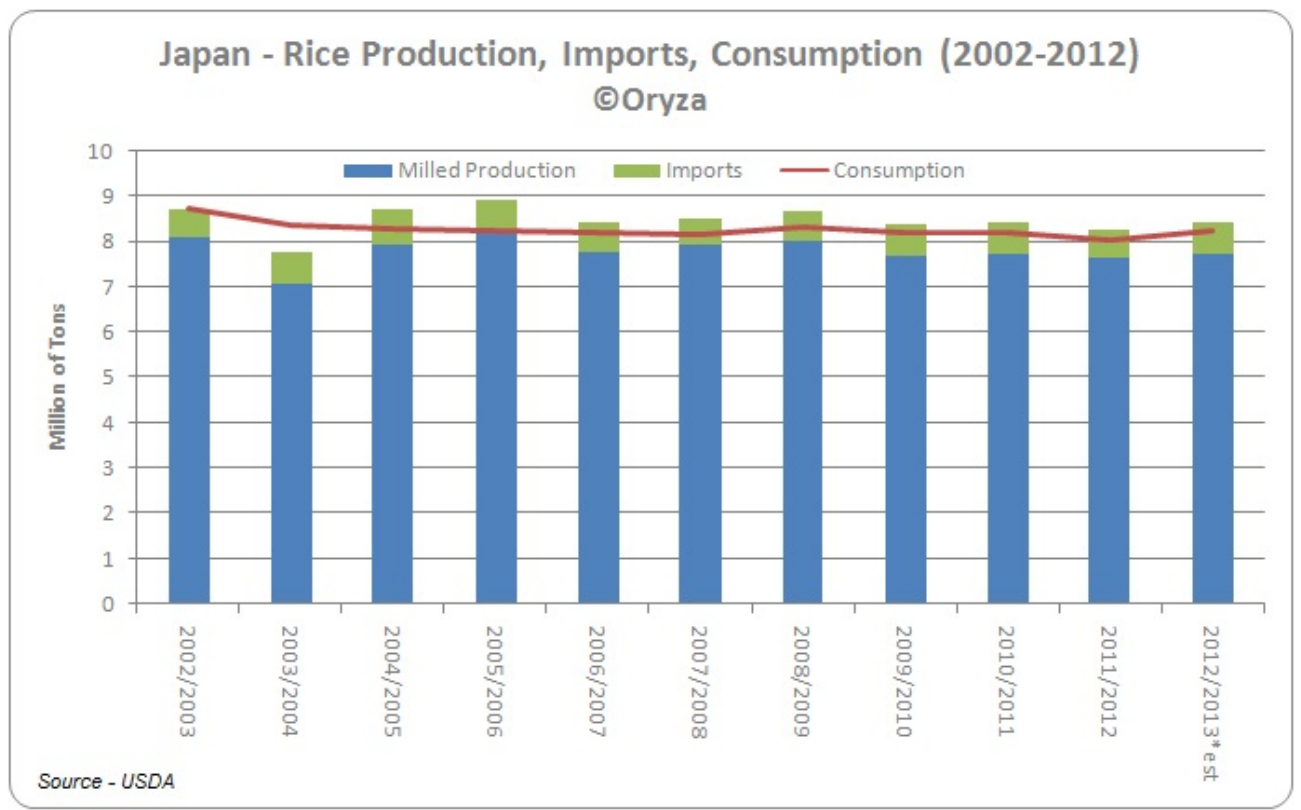

Figure 2.

\subsection{Diverse Rice Ecosystems}

The environmental and socio-economic conditions of rice production vary greatly from country to country as well as from location to location. The diverse environmental and socio-economic conditions have affected the performance of rice production in the past 45 years. They also influence the opportunities for increasing rice production in the future. Environmentally, rice is grown under different climates including temperate, sub-tropical and tropical. Within a climate the weather varies from arid and semi-arid to sub-humid and humid. Based on soil-water conditions rice production ecosystems include irrigated lowland, irrigated upland, rain fed lowland, rain fed upland and deepwater/floating ecosystems. Socio- economically, farm size cultivated by a household in South Asia, Southeast Asia, East Asia, and Africa is generally small, which varies from less than one hectare to few 
hectares. The ratio of rice land to arable land is high in South Asia, Southeast Asia, and East Asia. With the exception of Japan and Korea Rep, rice cultivation in South Asia, Southeast Asia, East Asia, and Africa still uses enormous amounts of human labor, in spite of strikes made in mechanization of rice production. On the other hand, farmers in Europe, America and Australia cultivate large farms and rice cultivation is highly mechanized with large expenditures of energy from fossil fuels.

\section{Issues and Technological Opportunities for Sustainable Rice Production}

The world's population continues to increase, although at lower growth rates. On the other hand global rice production is confronting issues such as climate change and the scarcity of water, land and energy resources. The issues and opportunities for sustainable increase of rice production differ from one rice ecosystem to another due to differences in environmental and socio-economic conditions, degrees of intensification, especially during the last 45 years, and crop management operations. Fortunately, there are existing improved and promising technologies that could be employed to boost farmers' production and to increase their incomes, while ensuring environmental conservation.

\subsection{Genetic Improvement}

Yield potential of both japonica and indica rice, especially of irrigated lowland rice, has greatly increased thanks to genetic improvement. Before the Meiji period japonica rice yields in Japan were low. The discovery of the variety Shinriki that had a short stem and produced outstanding yield when applied with high rates of fish-based fertilizer had increased rice yield and production. Consequently Shinriki was then used in the development of high-yielding japonica rice varieties in Japan and later in other countries where japonica rice is widely cultivated.

The cost of developing new varietals of rice is quite costly and is generally undertaken by multinational companies such as Pioneer, Monsanto, and LG Seeds. It is estimated that inbreds that are crossed with other inbreds to create hybrid seeds that are durable in the face of droughts and pests. One inbred line can take five to eight years of research and can cost $\$ 30$ million to $\$ 40$ millions to develop. This has created agricultural espionage by some Chinese in connection with the Chinese Academy of Sciences to steal seeds from Monsanto and other companies in order to reduce the time and cost of developing new seeds (Elgion \& Zuo, 2014: A12 \& A15).

\subsection{Minimizing the Effects of the Scarcity of Water, Land, and Labor Resources}

The following recommendations are largely taken from Van Nguyen. Water and land resources for rice production are being threatened by the competing needs of the cultivation of other food, feed and energy crops and the expansion of industrialization, urbanization. In addition, the migration from rural to urban areas in Asia and Africa has decreased substantially the labor resources, especially male labor in agriculture. In addition to the adoption of high-yielding and early maturing rice varieties, the application of combinations of existing technologies would save time, land and water for intensification of rice production in the future:

Minimum and/or zero tillage: The common benefits of conventional land preparation in rice production are weed control, incorporation of fertilizers, increase in soil porosity and aeration, mixing the soil to bring up leached deposits and giving the soil a good condition to increase adsorption of nutrient. However, conventional land preparation consumes time and energy. Moreover, in lowland ecosystems land preparation consumes about 30\% of the total amount water used in rice production, while in upland ecosystems it exposes soils to water and wind erosion. The search for substitute function of tillage operations has led to minimum and/or zero tillage practices. The main benefits of minimum and/or zero tillage practices are conservation of organic matter and soil moisture, reduction in water and wind erosion, reduction in fuels and animal and human energy, and time and water required for land preparation, and possible provision of favorable environment for biological activity. The adoption of minimum and zero tillage in rain fed upland rice production in Asia and Sub- Saharan Africa is still limited. Similar observation was true among rain fed irrigated lowland rice farmers. However, the adoption of minimum and zero tillage among rain fed upland rice farmers in Brazil who have the tradition of using large tractors to prepare land has increased in the recent past. The main constraint of the application of minimum or zero tillage in rice production is weed competition. Application of herbicides is currently used to suppress early weed growth in minimum or zero tillage in rice production. The development of alternative weed management approach would contribute to the adoption of minimum or zero tillage in rice production.

Land levelling using laser beam: In rain fed and irrigated lowland rice ecosystems, it is essential to have land levelled for good water management and also for weed control and the efficiency of nitrogen use. Farmers, especially in Asia, have the tradition to do soil puddling for land levelling. However, soil puddling requires substantial water and time. Land levelling using laser beam was developed for land levelling and its adoption is 
increasing worldwide, thanks to the advance in farm mechanization.

Direct seeding in lowland rice production: Farmers in Asia and Africa have the tradition of transplanting lowland rice. Transplanting uses less seed but requires more labor, time and water. It normally requires about 120 man-hours to transplant a hectare. Direct seeding on dry soils has been used by lowland rice farmers in Asian countries such as Indonesia and Philippines who grow two rice crops within a year in rainfed areas with long rainy season. The system is called gogo-rancha in Indonesia and sabog-tanim in the Philippines. In USA, irrigated lowland rice farmers use direct seeding on dry soils. Direct seeding onto flooded and saturated soils has been used by farmers in South America and Europe. The adoption of direct seeding onto flooded and saturated soils has increased in Asia due to labor shortage in rural areas. Direct seeding, however, requires large quantities of seed. Also weed competition in direct seeded fields is high.

Rotational and intermittent irrigation: Rice thrives well in both flooded and dry field as long as water supply is assured. Experiments conducted by the International Rice Research Institute in the 1970s show that yields of irrigated lowland rice were highest when fields were maintained at saturated level. In addition, rotational irrigation was found to be the most efficient operation in irrigation systems. Farmers in rainfed lowland rice ecosystems build bunds to store rain water as measure to prevent possible drought caused by erratic rainfall distribution. Also, lowland rice farmers flood rice field as a way to keep down weed competition. Improvement in weed management would promote the adoption of rotational and intermittent irrigation to increase the efficiency of water use in irrigated lowland rice production.

Aerobic rice or irrigated upland rice: Water consumption in aerobic rice ecosystems was lower than that in flooded lowland rice systems. Yields of aerobic rice, however, are still about $80 \%$ of that in irrigated lowland rice ecosystems. Moreover, in Brazil yields of aerobic rice decrease substantially in areas where rice was cropped continuously. Trade (WTO) \& Regional Trade Organizations (NAFTA)

The farming community is a much cherished sector throughout the world dating back to the early agrarian days of nation states. In the United States and in the European Union farmers have been subsidized for decades. And some specialized groups have received special treatment by the U.S. trade office. For example, Gilroy, California lobbied the International Trade Organization (ITO) in the U.S. successfully to impose a 376 percent $\%$ tariff on Chinese garlic to protect their virtual monopoly on garlic trade in the U.S.. Domestic farmers began struggling shortly after the first Chinese bulbs came to the United States in 1993, when they underpriced American garlic despite the extremely high tariffs (Cropchoice, 2003). As an aside, it was in 1993 that I was in Jinan, Shandong Province, China when I was quite amazed at the size of the garlic cloves a friend had purchased for 5 yuan when the exchange rate was 8 yuan to the U.S. dollar. After meeting with some province officials, it was established that I could import that garlic to the U.S.. Unfortunately, as I was in the process of procuring the various import licenses needed, the ITC came out with the report establishing the extreme tariff of more than $300 \%$. The feasibility of the venture became untenable at that point.

As a result of the protectionism, Japanese consumers pay more than twice the global average for rice and four times more for wheat. As recently described, the Japan Agricultural Group (J.A.) employs about 216,000 people in the agricultural cooperatives. This equates to one cooperative employee for every two farmers. Furthermore, the central government's 2.3 trillion yen farming budget for the current year is seven times the budget to oversee the remaining 99 percent nonagricultural economy. The tiny farms find it difficult to achieve economies of scale that makes them dependent on the cooperatives that buy their rice. The cooperatives also sell machinery, fertilizers, and pesticides to the farmers as well as serving as their financiers (Tabuchi, 2014: B2). The cooperatives also represent a means to garner votes for politicians in the rural areas. This has recently been discussed where in Thailand, the rice subsidies are running out of money and some farmers are not being paid. This is expected to be a critical concern for Prime Minister Yingluck Shinawatra whose political future is dependent on support from farmers and other rural voters. The Thai state incurs costs of 300 billion baht a year to support rice prices, amounting to $2.5 \%$ of GDP. Further, approximately 10 million tons of unprocessed rice has not been paid for by the government, worth 170 billion baht (approx. $\$ 5.190$ billion) (Watts et al., 2014: A11). Since it began in October of 2011, the rice subsidy program has cost the government about 670 billion baht (approximately $\$ 20$ billion. For clarification, the government buys rice from local farmers at close to $50 \%$ above market rates to improve the livelihood of the farmers (Chomchuen, 2014: A9).

In December of 2013, the Trans-Pacific Partnership (TPP) that includes Japan, United States and ten other Pacific Rim countries, was halted over the protections given to the rice farming sector. Akari Amari, Japan's trade minister, declared that Japan will not yield on its farming tariffs (Tabuchi, 2014) Japan has signed only a few limited free trade agreements, due to its tough stance on agricultural tariffs. Tokyo has always insisted that agricultural produce like rice 
and dairy stay exempt from the tariff reductions. Besides the high rice tariffs, Japan levies a 252 percent tariff on imported wheat, 360 percent on butter, 328 percent on sugar and 38.5 percent for beef. Perhaps the idea of a subsidy might be considered in lieu of the tariffs in order to increase Japan's ability to enjoy the benefits of freer trade, especially for their industrial sector.

Trade disputes between Japan and United States have been taking place over many decades. For example, in May of 1978, the United States imposed tariffs on imported steel from Japan referred to as the trigger price system. The trigger price mechanism establishes a floor price for foreign steel products. Under the current trigger price system, import prices are pegged to production prices in Japan, the world's most efficient steel producer. The price for imported steel was more than $\$ 500$ a ton in 1981 - the trigger price was $\$ 422.95$ in April of 1981 (New York Times, 1981).

Recently, Japan announced that it will drastically expand the sanctions it imposes against exports of U.S. products in retaliation for the continued distribution of antidumping and countervailing duty revenues to affected U.S. producers under the Continued Dumping and Subsidization Offset Act, or Byrd Amendment. The level of these sanctions is dependent on the amount of revenues collected from imports of Japanese products subject to AD or CV duty orders that were distributed in the previous year, which jumped from \$1.96 million to \$103.43 million in fiscal year 2012 . The value of U.S. exports targeted by Japan will therefore balloon from $\$ 1.41$ million to $\$ 74.47$ million. Accordingly, for the period September 1, 2013, through August 31, 2014, Japan will impose an additional 17.4\% duty on imports of the selected U.S. steel products (Sandler, Travis \& Rosenberg Trade Report, 2013).

\section{Innovation in a Traditional Industry}

As discussed above, rice cultivation is an ancient artifact and arguably, craft that has undergone very little change in the rice cycle that comprises five main phases: sowing, planting out, growth, maturity, harvest. The industry is structured similarly throughout the world with the exception of rice farms in the United States and Europe. Malcolm Gladwell claimed in his book Outliers that "working in a rice field is ten to twenty times more labor-intensive than working on an equivalent-size corn or wheat field. Some estimates put the annual workload of a wet-rice farmer in Asia at three thousands hours a year."

Rice is so important in Japanese society that it has been called the essence of the culture. Even a superficial examination of Japanese culture reveals the complex connection rice has to many of its forms and expressions, in both historical and contemporary settings (Wojtan, 1993). As suggested by Egenter (1996) Japanese rice production also has to do with culture in a quite different sense, cultivation this time being closely interwoven with a cult. In fact, in traditional rice cultivation the rice is not simply produced. Its whole cycle is instead treated as a cultic happening. If this aspect is not considered as culture, it is only because it has turned into a matter of religion. And because of its theological approach, this religion has no appreciation of the concrete facts of farming. It sets out from the spiritual conceptions of belief and primitivizes the cultural content by measuring it against the abstractive powers of the mind. It consequently works only with ideas, such as the "rice soul", and presents the cultural content as a hierarchy of values ranging from the established cults of the divinities of Shinto to those of the divinities of popular belief, and ending with peasant festivals and annual customs that have very little to do with religion. Those who have studied the customs at close quarters and have investigated their spatial and temporal structures must realize that such primitivization can only be caricature. In reality a rich culture comes to light, and one that has its own philosophy of life. It is concerned with safeguarding the farmer's existence in space and time.

It has been suggested that due to the industrial structure of the Japanese rice industry the quality of the cultivated rice is mediocre. The ability to increase the size of one's farm is limited by rural land policy. However, a young farmer, Hiromitsu Konsho, started an organic rice farm, Echigo Farm in the rice-growing region of Niigata (please see Figure \#3). His organic rice sells locally and internationally for 5,500 yen per kilogram (about \$24 a pound). It is rare for a younger people to enter into the rice industry where three quarters of Japanese farmers are over 60 years of age (Tabuchi, 2014: B1 \& B2). 


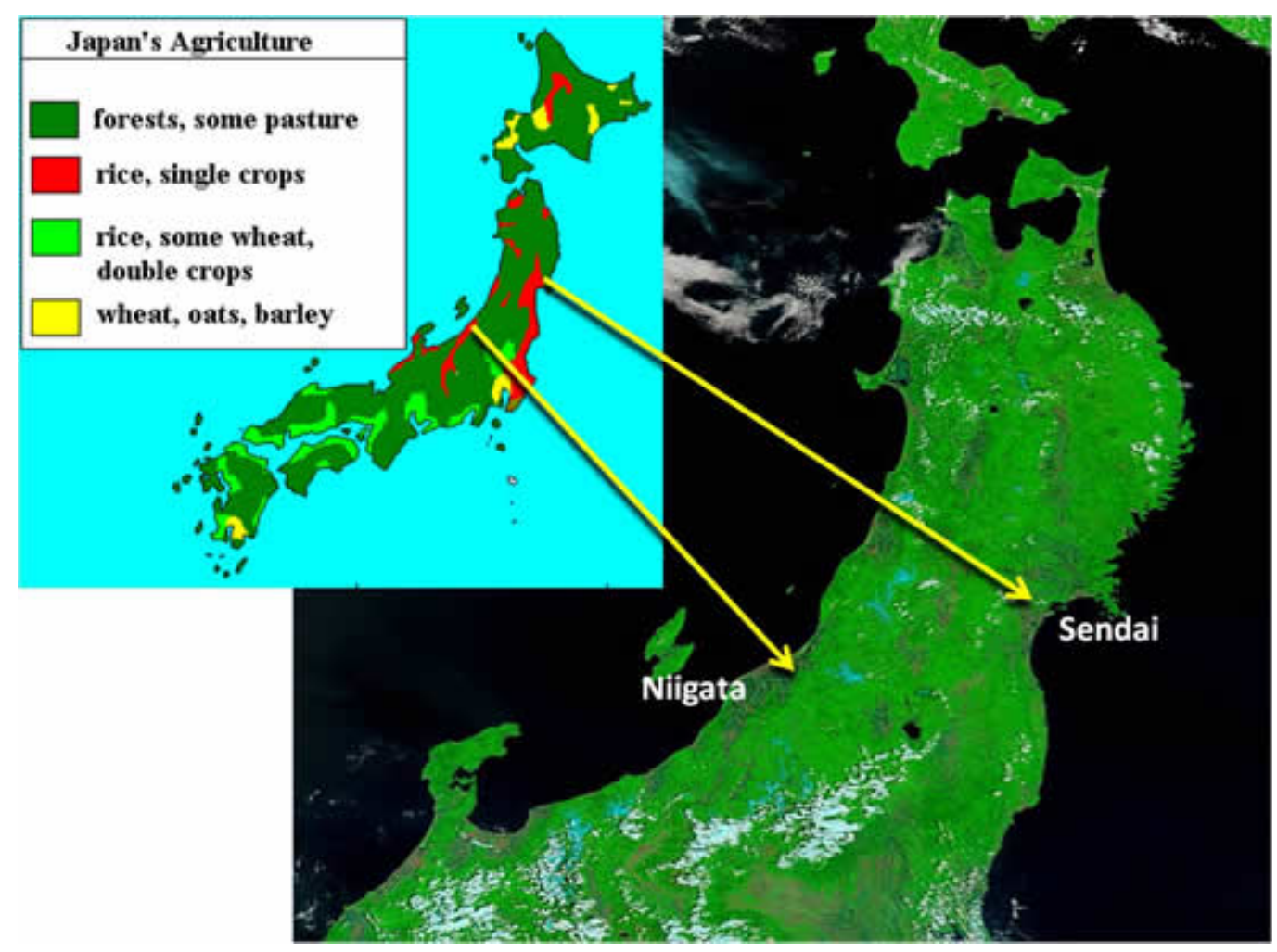

Figure 3.

Source: http://www.pecad.fas.usda.gov/highlights/2012/08/Japantrip/

Also, as mentioned above, bioengineering may be used to improve the quality of the rice crop through cross breeding strains for improved flavor as well as the durability of the crop. Drought, high salinity, and low temperature are the most common environmental stress factors that influence plant growth and development and place major limits on plant productivity in cultivated areas worldwide. To overcome these limitations and improve crop yield under stress conditions, it is important to improve stress tolerance in crops (Rabbani et al., 2003). For example, in Egypt researchers showed that transferring a single gene from barley to wheat, plants are able to tolerate reduced watering longer. This variety requires only one-eighth as much irrigation as conventional wheat and can be cultivated with meager rainfall alone (Lusk \& Miller, 2014). Further, as discussed by Chodhury and Kennedy (2004), the nitrogen requirement of rice crops is well known. To overcome acute $\mathrm{N}$ deficiency in rice soils, this element is usually supplied to the rice crop as the commercially available fertilizer urea. But unfortunately a substantial amount of the urea-nitrogen is lost through different mechanisms causing environmental pollution problems. Utilization of biological nitrogen fixation (BNF) technology can decrease the use of urea-nitrogen, reducing the environmental problems to a considerable extent. Different biological nitrogen fixation (BNF) systems have different potentials to provide a nitrogen supplement, and it is necessary to design appropriate strategies in order to use BNF systems for efficient nitrogen supply to a rice crop.

\section{Conclusion}

Protecting the Japanese rice farmers, and generally the farming sector, comes at a high cost for the industrialized sector as it serves as impediment to establishing free trade agreements. In particular, joining the Trans-Pacific Partnership is critical for the future economic growth in Japan as the vast free-trade area that would involve over half of the world's economic output. Furthermore, in a modern era, the level of protection for the rice farmers in Japan is not sustainable, as it is arguably undermining innovative farming activity in the product and processes of the rice industry. Furthermore, climate change is reducing the availability of water resources throughout the world suggesting that it is imperative for new methods of efficient and renewable irrigation be employed as well as developing genetically modified crops that require less water and fertilizers. 


\section{References}

Choudhury, A. T. M. A., \& Kennedy, I. R. (2004). Prospects and Potentials for Systems of Biological Nitrogen Fixation in Sustainable Rice Production. Biol Fertil Soils, 39, 219-227.

Chomchuen, W. (2014). Graft Inquiry Targets Thailand's Premier. Wall Street Journal, January 17, A9.

Cropchoine. (2003). California farmers give up garlic battle. Retrieved from www.cropchoice.com/leadstryed $7 \mathrm{c}$. html? recid=1901

Egenter, N. (1996). Japanese Rice Culture: The Misunderstood Philosophy of the Agrarian Past. Retrieved from http://home.worldcom.ch/ negenter/473bTx_E01.html

Elgion, J., \& Zuo, P. (2014). Designer Seed Thought to Be Latest Target By Chinese. New York Times, February 5, A12 $\&$ A15.

Flynn, D. (2012). Sustainable Development, Climate Change and Natural Resource Scarcity. The International Journal of Climate Change: Impacts and Responses, 4(3), 61-76.

Flynn, D. M. (1985). Organizational and Environmental Effects on Innovation: A Comparison of Two Cultures. Asia-Pacific Journal of Management, 2(3), 150-163.

Flynn, D. M. (1982). Japanese Values and Management Processes. In Lee, S. M., \& Schwendiman, G. (Eds.), Japanese Management. N.Y.: Praeger, 72-81.

Flynn, D., Eddy, E., \& Tannenbaum, S. I. (2006). The Impact of National Culture on the Continuous Learning Environment: Exploratory Findings from Multiple Countries. Journal of East-West Business, 12, 2 \& 3, 85-107.

Gladwell, M. (2011). Outliers: The Story of Success. New York: Back Bay Books.

Hermanowicz, S.W. (2005). Entropy and Energy: Toward a Definition of Physical Sustainability. Working Paper. Retrieved from http://repositories.cdlib.org/wrca/wp/swr v2

Hofstede, G. (1980). Cultures Consequences. Beverly Hills: Sage Publishers.

Japan Times. (2014). Japan's population falls by a record 244,000 in 2013. Retrieved from www.japantimes.co.jp/news/2014/01/01/national/japans-population-falls-by-a-record-244000-in-2013/\#.UtlyZ_ Yo7-Y

Lant, C. (2004). Water Resources Sustainability: An Ecological Economics Perspective. Water Resources Update, $127,20-30$.

Lusk, J., \& Miller, H. I. (2014). We Need to G.M.O. Wheat. New York Times, February 3, A23.

Murayama, M. (1971). Japanese Business Value System. Sophia Economic Review, XVII, 3, 1-28.

New York Times. (1981). Business Conditions; Steel's Trigger Rises. February 22. Retrieved from www.nytimes.com/1981/02/22/business/business-conditions-steel-s-trigger-rises.html

Rabbani, M. A., Maruyama, K., Abe, H., Khan, M. A., Katsura, K., Ito, Y., Yoshiwara, K., Seki, M., Shinozaki, K., \& Yamaguchi-Shinozaki, K. (2003). Monitoring Expression Profiles of Rice Genes under Cold, Drought, and High-Salinity Stresses and Abscisic Acid Application Using cDNA Microarray and RNA Gel-Blot Analyses. Plant Physiology, December 13, 4, 1755-1767.

Reichel, A., \& Flynn, D. M. (1983). Values in Transition: Japanese Managers in the U.S. Management International Review, 3(4), 63-72.

Sandler, Travis, \& Rosenberg Trade Repost. (2013). Japan Targets U.S. Bearings, Steel for Additional 17.4\% Tariffs in Trade Dispute. August 29.

Tabuchi, H. (2014). Japanese Begin to Question Protections Given to Homegrown Rice. New York Times, January 10, B1 \& B2.

Tabuchi, H. (2010). Japan's Farmers Oppose Free-Trade Talks. New York Times, November 11. Retrieved from www.nytimes.com/2010/11/12/business/global/12yen.html?pagewanted=all\&_r=0

Van Nguyen, N. Sustainable Intensification of Rice Production for Food Security in the Near Future - A Summary Report. Retrieved from www.fao.org/fileadmin/templates/agphome/documents/Rice/sustintriceprod.pdf

Watts, J. K., Steger, Is., \& Watcharasakwet, W. (2014). Rice Opens Rift in Thailand. Wall Street Journal, January 16.

Wojtan, L.S. (1993). Rice: It's More Than Food In Japan. November. Retrieved from 
http://spice.stanford.edu/docs/145

Yomiuri Shimbun. (2014). Retrieved from http://the-japan-news.com/news/article/0000957239 http://heritageofjapan.wordpress.com/ 